DOI:10.17951/h.2015.49.4.589

\begin{tabular}{lcl}
\hline \multicolumn{3}{c}{ A N N A L E S } \\
UNIVERSITATIS & MARIAE CURIE-SKŁODOWSKA \\
LUBLIN - POLONIA \\
VOL. XLIX, 4 & SECTIOH \\
\hline
\end{tabular}

Uniwersytet Marii Curie-Skłodowskiej, Wydział Ekonomiczny

\title{
JOANNA ŚWIERK
}

joanna.swierk@umcs.lublin.pl

\section{Pomiar dokonań jednostki samorząu terytorialnego przy wykorzystaniu strategicznej karty wyników na przykładzie gminy Inowroctaw}

\footnotetext{
Measuring the Performance of Local Government Using the Balanced Scorecard on the Example of Inowrocław Community
}

Słowa kluczowe: strategiczna karta wyników, jednostka samorządu terytorialnego, mierniki

Keywords: Balanced Scorecard, Local Government, measures

Kod JEL: M49

\section{Wstęp}

Obecnie z uwagi na zmiany w otoczeniu, ograniczoność zasobów, a przede wszystkim rosnący poziom zadłużenia sektora publicznego coraz większym wyzwaniem staje się efektywne zarządzanie jednostką samorządu terytorialnego. Wymusza to konieczność wykorzystywania narzędzi umożliwiających skuteczne wdrażanie i monitorowanie obranej przez organizację strategii rozwoju. Rozwiązania takie od wielu lat $\mathrm{z}$ powodzeniem funkcjonują już w przedsiębiorstwach sektora prywatnego i coraz częściej są stosowane przez jednostki publiczne, takie jak gminy, uczelnie czy szpitale. Jedną z takich koncepcji ułatwiającą zarządzanie organizacją jest strategiczna karta wyników.

Strategiczna karta wyników, opracowana przez Kaplana i Nortona, jest narzędziem przekładającym misję i strategię jednostki na działania operacyjne i cele 
indywidualne dla poszczególnych pracowników [Kaplan, Norton, 2001, s. 11-13]. Mierzy ona efektywność działań organizacji w sposób zrównoważony w czterech perspektywach: finansowej, klienta, procesów wewnętrznych oraz wiedzy i rozwoju. Za pomocą przypisanych mierników finansowych i niefinansowych, krótkoterminowych i długoterminowych, mierzy strategię i dokonania jednostek. Strategiczna karta wyników wraz z systemem miar tworzy łańcuch relacji przyczynowo-skutkowych, ukazując, jak organizacja przez inwestowanie w zasoby ludzkie, systemy informatyczne oraz realizowane procesy przyciąga klientów i poprawia wyniki finansowe.

Odpowiednio zmodyfikowana do potrzeb i specyfiki celów jednostek samorządu terytorialnego strategiczna karta wyników staje się narzędziem implementacji strategii rozwoju gminy oraz systemem mierzenia jej dokonań.

Celem artykułu jest ukazanie istoty pomiaru dokonań jednostki samorządu terytorialnego i zaprezentowanie możliwości zastosowania strategicznej karty wyników do mierzenia realizacji strategii rozwoju gminy Inowrocław.

\section{Pomiar wyników i zarządzanie jednostką samorządu terytorialnego}

Wśród zasad nowego zarządzania publicznego (NPM), postulowanego do wdrożenia przez jednostki samorządu terytorialnego, wymieniane są m.in. wprowadzenie profesjonalnego zarządzania, poprawa skuteczności i efektywności działania jednostek sektora publicznego oraz podniesienie jakości świadczonych usług. Dodatkowo celem owego zarządzania jest ustalenie jasno określonych standardów i mierników, nacisk na kontrolę wyników, a także większa dyscyplina i oszczędność wykorzystywanych zasobów [Zalewski (red.), 2007, s. 27]. Wynika z tego, iż działalność jednostek sektora publicznego, w tym gmin, w coraz szerszym zakresie zostaje ukierunkowana na osiągane wyniki (rys. 1).

Przedstawiona koncepcja pomiaru wyników w jednostkach samorządu terytorialnego jest podejściem holistycznym, uwzględniającym interesy wszystkich interesariuszy. Umożliwia formułowanie celów i strategii zarówno z punktu widzenia polityczno-administracyjnego, jak i z perspektywy mieszkańców. Pomiar wyników w tej koncepcji uwzględnia, oprócz zależności pomiędzy ilością i jakością świadczonych usług oraz stopniem realizacji celu, także zależności pomiędzy stopniem realizacji celu oraz programami politycznymi i zaufaniem społeczeństwa. Jak podkreśla W. Skoczylas, ten sposób pomiaru wyników uwzględnia trzy płaszczyzny: płaszczyznę mikro (sprawności), płaszczyznę mezo (identyfikacja działań zawartych w akceptowanych programach politycznych, koniecznych dla poprawy jakości życia społeczności lokalnej) oraz płaszczyznę makro (zaufanie mieszkańców i interesariuszy do administracji publicznej i urzędników) [Skoczylas, 2011b, s. 236]. Idealnym rozwiązaniem uwzględniającym te płaszczyzny, a przy tym bazującym na mierzeniu dokonań jednostki samorządu terytorialnego, jest strategiczna karta wyników. 
Pobrane z czasopisma Annales H - Oeconomia http://oeconomia.annales.umcs.pl Data: 26/04/2023 15:53:24

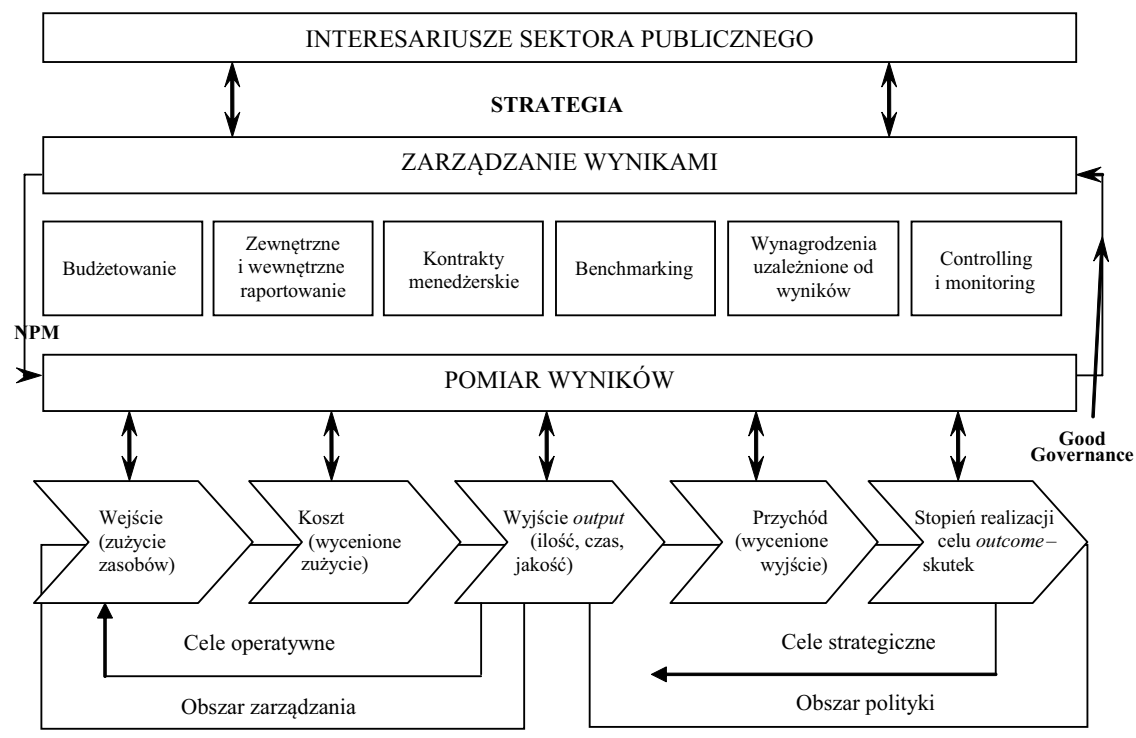

Rys. 1. Pomiar wyników w sektorze publicznym

Źródło: [Skoczylas, 2011b, s. 235].

\section{Mierniki w strategicznej karcie wyników dla jednostki samorządu terytorialnego}

Strategiczna karta wyników (SKW) stanowi kolejny poziom mierzenia i oceny efektywności jednostki samorządu terytorialnego (rys. 2). Ujmuje działalność JST w ujęciu długookresowego planu, a nie jednorocznego budżetu. Inaczej niż w budżecie zadaniowym rozpisuje cele strategiczne na zadania na szczeblu wykonawczym. Przez analizę wykonania założeń strategicznych na podstawie uzyskanych wskaźników, pozwala na identyfikację czynników i zasobów mających wpływ na przyszłe wyniki gminy.

JEDNOROCZNE UJECIE DZIALALNOŚCI

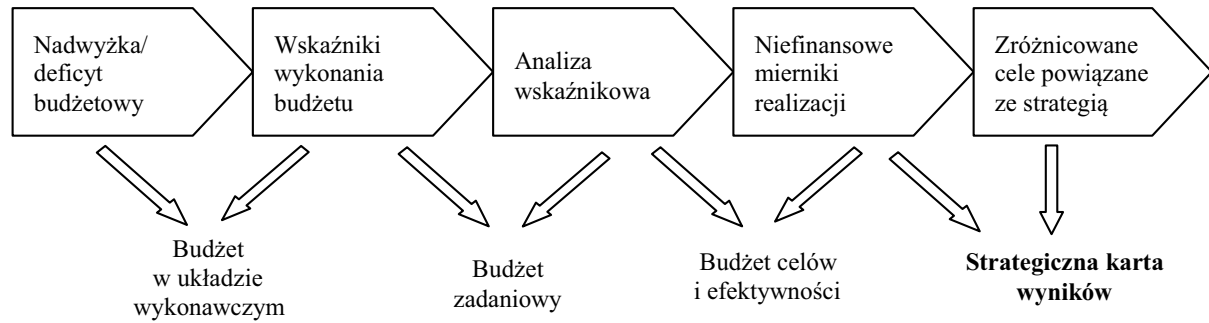

Rys. 2. Ewolucja systemów zarządzania i oceny jednostek samorządu terytorialnego 
Opracowanie mierników dla poszczególnych perspektyw SKW powinno przebiegać zgodnie z ustaloną dla gminy kolejnością. Ogólna metodologia ich tworzenia obejmuje następujące cztery etapy [Świderek, 2012, s. 135-135]:

Etap 1. Przyporządkowanie wskaźników do odpowiedniej perspektywy działalności (finansowej, klienta, procesów wewnętrznych, rozwoju).

Etap 2. Zakwalifikowanie do odpowiedniej grupy mierników (produktywności, jakości, zyskowności, czasochłonności, wydajności, długości cyklu, zużycia zasobów, kosztów, wzrostu, innowacyjności, technologii).

Etap 3. Określenie jednostki miernika i standaryzacja (wielkości absolutne, wielkości względne).

Etap 4. Określenie charakteru miernika (krótkoterminowy - długoterminowy, strategiczny - taktyczny, główny - pomocniczy, ilościowy - wartościowy, wewnętrzny - zewnętrzny, procesowy - wynikowy, planowany - kontrolny).

Ustalanie i wybór mierników do poszczególnych celów strategicznych jest dokonywane z uwzględnieniem zasady SMART. Oznacza to, iż mierniki powinny być skonkretyzowane (S), mierzalne (M), akceptowalne (A), realne (R) oraz posiadające termin realizacji $(\mathrm{T})$. Tak opracowane mierniki umożliwiają zarządzanie gminą, obrazując stopień realizacji wyznaczonych celów. Dzięki temu tworzą system mierzenia strategii.

Efektywny system mierników dla poszczególnych perspektyw SKW powinien charakteryzować następujący wykaz cech [Niemiec, 2008, s. 22-23]:

- integrujący - mierniki powinny być powiązane ze strategią i systemem celów,

- przypisywalny - każdy miernik powinien być przypisany osobie lub grupie osób odpowiedzialnych za osiąganie wyniku w danym obszarze,

- prospektywny - mierniki są miarami nośników wartości, dzięki czemu za ich pomocą można oceniać obecne i przewidywać przyszłe wyniki organizacji,

- umożliwiający reakcję - mierniki dostarczają na czas informacji, na podstawie których możliwe jest reagowanie i podejmowanie działań,

- nieliczny - powinien koncentrować uwagę menedżerów na kilku istotnych problemach,

- zrozumiały - mierniki powinny być przejrzyste i proste,

- zrównoważony i adekwatny - zestaw mierników powinien zawierać różne rodzaje mierników, które nie wykluczają się wzajemnie,

- nośnik zmian - mierzenie dokonań organizacji powinno inspirować wdrażanie zmian w sposobie zarządzania,

- standaryzowany - mierniki, metodologia liczenia i ich zdefiniowanie powinny być jednakowe dla całej organizacji,

- odniesiony do kontekstu - przez powiązanie z celami strategicznymi umożliwia komunikowanie strategii w dół struktury organizacyjnej oraz jej kontrolę przez wyższe szczeble zarządzania,

- motywujący - istnieje możliwość powiązania systemu mierników z systemem motywacyjnym, jeśli jest on zrozumiały i stabilny w czasie, 
- stosowny - system mierników powinien być okresowo oceniany i modyfikowany, aby na bieżąco odzwierciedlał zmieniające się otoczenie.

Tak opracowany system mierzenia strategii powinien przyczynić się do wdrożenia założeń strategicznych jednostki samorządu terytorialnego oraz bieżącego śledzenia postępów w jej osiąganiu. Pomiar wyników gminy może być zastosowany również do formułowania strategii i przedstawiania jej oceny, motywowania pracowników, a także wewnętrznego i zewnętrznego raportowania [Skoczylas, 2011a, s. 674].

\section{Strategiczna karta wyników dla gminy Inowrocław}

Opracowana Strategia Rozwoju Gminy Inowrocław jest planem realizacji długofalowych zamierzeń ustalonych na lata 2013-2020. Obrazuje ona przejście z aktualnej sytuacji do pożądanego stanu w przyszłości. W strategii sformułowano na nowo misję i wizję gminy. Misja wyraża główny powód istnienia jednostki oraz wartości, które wyznaje samorząd, dbając o rozwój gminy i dobro jej mieszkańców. Natomiast wizja rozwoju gminy określa stan docelowy, do którego władze lokalne oraz ich partnerzy będą dążyć, wykorzystując mocne strony posiadanych zasobów oraz szanse pojawiające się w najbliższym otoczeniu [Strategia Rozwoju Gminy Inowrocław..., 2013, s. 3-7]. Misję i wizję rozwoju gminy Inowrocław przedstawiono na rys. 3.

\section{Misja gminy Inowroclaw}

Efektywne zaspokajanie zbiorowych potrzeb mieszkańców gminy Inowrocław oraz zapewnienie im szans na lepszą przyszłość.

\section{Wizja rozwoju gminy Inowroclaw}

Gmina Inowrocław miejscem, w którym jej mieszkańcy żyją godnie i bezpiecznie, współuczestnicząc i realnie decydując o jej rozwoju i sposobie działania. Coraz wyższy standard życia mieszkańców będzie wynikiem aktywizacji gospodarczej terenu gminy Inowrocław oraz jej rosnącej konkurencyjności w stosunku do gmin sąsiednich, opartej na trwałym, strategicznym i wieloaspektowym partnerstwie pomiędzy trzema sektorami: publicznym, społecznym i gospodarczym.

Rys. 3. Model strategicznej karty wyników dla gminy Inowrocław

Źródło: [Strategia Rozwoju Gminy Inowrocław..., 2013, s. 6, 7].

Ustalona misja daje podstawę do określenia kluczowych wartości wyznawanych przez jednostkę. Na systemie wartości powinny opierać się wszystkie podejmowane decyzje i zachowania pracowników [Świerk, 2009, s. 87-88]. Wśród najważniejszych wartości kluczowych wyznawanych w codziennym działaniu gminy Inowrocław znajdują się [Strategia Rozwoju Gminy Inowroctaw..., 2013, s. 6]:

- wysokie zaangażowanie pracowników wyrażające się indywidualnym podejściem do spraw i problemów każdego interesanta gminy, 
- odpowiedzialność oznaczająca, iż wszystkie działania i zadania podejmowane w gminie są odpowiednio wcześniej planowane, sprawnie realizowane i efektywnie kontrolowane, aby skutecznie osiągnąć założone cele.

Sformułowana misja, kluczowe wartości oraz wizja stanowiły punkt wyjścia do ustalenia celów strategicznych gminy. Dla gminy Inowrocław ustalono 18 celów rozwojowych przyporządkowanych do czterech perspektyw (rys. 4).

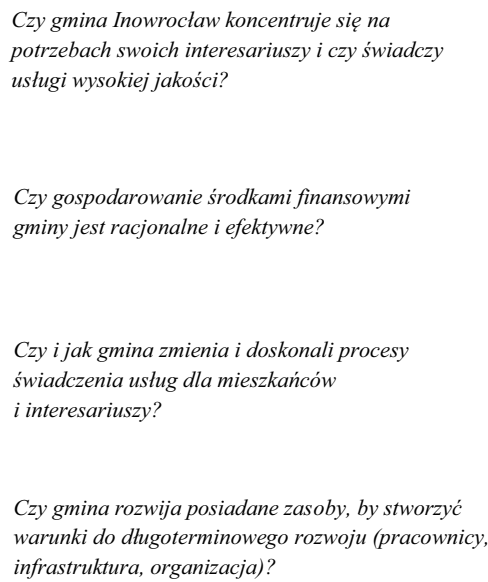

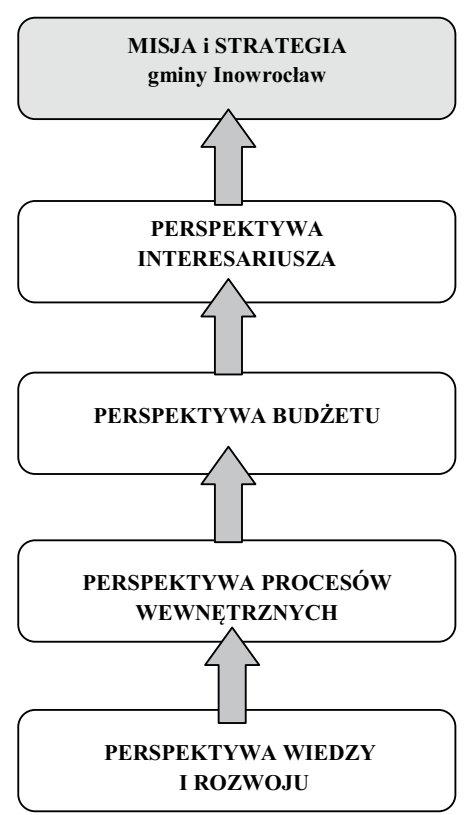

Rys. 4. Model strategicznej karty wyników dla gminy Inowrocław

Dodatkowo określono trzy wybory strategiczne prezentujące kierunki i dążenia gminy do stworzenia wyjątkowej wartości dla swoich mieszkańców [Strategia Rozwoju Gminy Inowrocław..., 2013, s. 21]:

1. Zrównoważyć budżet gminy.

2. Zbudować trwałe partnerstwo sektora publicznego, społecznego i gospodarczego.

3. Zwiększyć konkurencyjność gminy Inowrocław w stosunku do gmin sąsiednich.

W przypadku jednostki samorządu terytorialnego na samej górze strategicznej karty wyników umiejscowiona jest perspektywa interesariusza (klienta). Dla gminy, w ujęciu wąskim, klientem jest społeczność lokalna zamieszkująca jej terytorium. Oczekuje ona od gminy optymalnych warunków zamieszkania, warunków pracy oraz sprzyjającego jej środowiska przyrodniczego. W ujęciu szerokim klientami gminy są wszyscy, którzy wchodzą w relacje z gminą. Stanowią oni grupę interesariuszy, 
do których zalicza się przedsiębiorców i inwestorów, zarówno już istniejących, jak i potencjalnych. To właśnie od nich, ich ilości i aktywności uzależnione są dochody mieszkańców gminy oraz dochody do budżetu, które determinują ogólny poziom życia mieszkańców społeczności gminnej [Bielawski, 2014, s. 14].

W perspektywie klienta opracowano osiem mierników dla pięciu celów strategicznych. Na poziom bezpieczeństwa ruchu drogowego w gminie Inowrocław wpływa wiele czynników. Jednym z możliwych mierników jest liczba zrealizowanych interwencji przez policję lub straż miejską. Im bardziej wskaźnik będzie wykazywał tendencję malejącą, tym bezpieczniej mieszkańcy gminy będą czuli się na drogach. Zapewnienie dostępu do podstawowej infrastruktury technicznej może zostać zmierzone wartością nakładów finansowych oraz liczbą gospodarstw podłączonych w danym roku do infrastruktury wodno-kanalizacyjnej. O dostarczeniu mieszkańcom atrakcyjnych możliwości spędzania czasu wolnego może świadczyć liczba imprez kulturalnych organizowanych przez gminę oraz dostępność tras rowerowych i szlaków turystycznych dla mieszkańców. Atrakcyjność oferty edukacyjnej szkół z terenu gminy może zostać zmierzona liczbą uczniów uczęszczających do tych szkół. Dobrymi miarami dla realizacji wysokiego poziomu obsługi mieszkańców gminy są liczba skarg zgłaszanych przez interesariuszy oraz czas ich obsługi w urzędzie. Wykaz celów i opracowane mierniki dla pespektywy interesariusza prezentuje tab. 1.

Tab. 1. Cele i mierniki w perspektywie interesariusza strategicznej karty wyników dla gminy Inowrocław

\begin{tabular}{|l|l|}
\hline \multicolumn{1}{|c|}{ Cele strategiczne } & \multicolumn{1}{c|}{ Mierniki } \\
\hline $\begin{array}{l}\text { I1. Zapewnienie wysokiego poziomu bezpieczeństwa } \\
\text { ruchu drogowego. }\end{array}$ & I1.1. Liczba interwencji policji/straży miejskiej. \\
\hline $\begin{array}{l}\text { I2. Zapewnienie dostępu do podstawowej infrastruk- } \\
\text { tury technicznej (zwłaszcza wodno-kanalizacyjnej). }\end{array}$ & $\begin{array}{l}\text { I2.1. Wartość nakładów na infrastrukturę techniczną. } \\
\text { I2.2. Liczba gospodarstw domowych z infrastrukturą } \\
\text { wodno-kanalizacyjną. }\end{array}$ \\
\hline $\begin{array}{l}\text { I3. Dostarczenie mieszkańcom atrakcyjnej oferty } \\
\text { spędzania czasu wolnego. }\end{array}$ & $\begin{array}{l}\text { I3.1. Liczba organizowanych imprez kulturalnych. } \\
\text { I3.2. Długość tras rowerowych/szlaków turystycz- } \\
\text { nych. }\end{array}$ \\
\hline $\begin{array}{l}\text { I4. Zwiększenie liczby uczniów uczęszczających do } \\
\text { szkół na terenie gminy. }\end{array}$ & $\begin{array}{l}\text { I4.1. Liczba uczniów uczęszczających do szkół na } \\
\text { terenie gminy. }\end{array}$ \\
\hline $\begin{array}{l}\text { I5. Obsługiwanie mieszkańców gminy z największym } \\
\text { zaangażowaniem i na najwyższym poziomie. }\end{array}$ & $\begin{array}{l}\text { I5.1. Czas obsługi mieszkańców/interesariuszy. } \\
\text { I5.2. Liczba skarg zgłaszanych przez mieszkańców. }\end{array}$ \\
\hline
\end{tabular}

Źródło: opracowanie własne na podstawie: [Strategia Rozwoju Gminy Inowrocław..., 2013, s. 21-22].

Perspektywa budżetu z pięcioma celami strategicznymi obejmuje sześć mierników. Poziom kondycji finansowej jednostki świadczy o możliwościach finansowania przez gminę zadań i usług publicznych oraz stanowi miarę wywiązywania się gminy ze zobowiązań finansowych wobec interesariuszy (podatników, wyborców, kredytodawców, pożyczkodawców). Zwiększenie poziomu dochodów własnych może być zmierzone liczbą nowych mieszkańców gminy, liczbą nowych przedsiębiorstw zlokalizowanych na jej terenach oraz procentowym przyrostem dochodów $\mathrm{z}$ tytułu podatku rolnego. O racjonalnym wydatkowaniu środków na świadczenie 
usług publicznych świadczy stopień realizacji zaplanowanych w budżecie zadań. Zwiększenie udziału środków zewnętrznych w finansowaniu inwestycji jest celem mierzonym przez dwa mierniki: udział środków zewnętrznych i bezzwrotnych funduszy w całości środków gminy. Omówione mierniki wraz z celami strategicznymi dla perspektywy budżetu przedstawia tab. 2 .

Tab. 2. Cele i mierniki w perspektywie budżetu strategicznej karty wyników dla gminy Inowrocław

\begin{tabular}{|l|l|}
\hline \multicolumn{1}{|c|}{ Cele strategiczne } & \multicolumn{1}{|c|}{ Mierniki } \\
\hline $\begin{array}{l}\text { B1. Zwiększenie dochodów własnych w wyniku } \\
\text { pozyskania nowych mieszkańców gminy. }\end{array}$ & B1.1. Liczba nowych mieszkańców gminy. \\
\hline $\begin{array}{l}\text { B2. Zwiększenie dochodów własnych związanych } \\
\text { z tworzeniem warunków do prowadzenia działalności } \\
\text { gospodarczej. }\end{array}$ & B2.1. Liczba nowych przedsiębiorstw. \\
\hline $\begin{array}{l}\text { B3. Zwiększenie dochodów własnych z tytułu podat- } \\
\text { ku rolnego. }\end{array}$ & $\begin{array}{l}\text { B3.1. Procentowy przyrost dochodów własnych } \\
\text { z tytułu podatku rolnego. }\end{array}$ \\
\hline $\begin{array}{l}\text { B4. Racjonalizacja wydatków związanych ze świad- } \\
\text { czeniem usług publicznych. }\end{array}$ & B4.1. Stopień realizacji zaplanowanych zadań. \\
\hline $\begin{array}{l}\text { B5. Zwiększenie udziału środków zewnętrznych } \\
\text { w finansowaniu inwestycji. }\end{array}$ & $\begin{array}{l}\text { B5.1. Udział środków zewnętrznych w całości } \\
\text { środków. } \\
\text { B5.2. Udział bezzwrotnych funduszy w całości } \\
\text { środków. }\end{array}$ \\
\hline
\end{tabular}

Źródło: opracowanie własne na podstawie: [Strategia Rozwoju Gminy Inowrocław..., 2013, s. 21-22].

Dla ustalonych pięciu celów z perspektywy procesów wewnętrznych opracowano sześć mierników. Miernikiem dla skuteczności promocji gminy może być liczba turystów odwiedzających Inowrocław. Z kolei cel „atrakcyjna oferta edukacyjna” powinien być mierzony miejscem szkoły uzyskanym w różnych rankingach (przykładowo miejsce szkoły w rankingu wśród wyników szkół z egzaminu ,,szóstoklasity", gimnazjalnego, maturalnego w województwie kujawsko-pomorskim). Dobrym miernikiem informującym o przydatności platformy komunikacyjnej pomiędzy sektorem publicznym, społecznym i gospodarczym jest liczba zgłaszanych spraw przez organizacje z tych trzech sektorów. O sprawnie funkcjonującym systemie kontroli wydatków może świadczyć poziom procentowy realizacji budżetu. Stopień realizacji celu ,zapewnienie dobrze funkcjonującego systemu obsługi klienta" powinien być mierzony dwoma miernikami. Poziom zadowolenia klientów z obsługi oraz liczba spraw, które można załatwić przez Internet to przykłady miar świadczących o tym, iż gmina Inowrocław zwraca uwagę na usprawnianie realizacji procesu obsługi interesariuszy w urzędzie. Wykaz celów strategicznych i opracowanych do nich mierników dla perspektywy procesów wewnętrznych zawiera tab. 3 .

W perspektywie wiedzy i rozwoju dla trzech celów strategicznych opracowano cztery mierniki. Perspektywa ta wskazuje na posiadane przez gminę zasoby, które warunkują i przyczyniają się do realizacji wszystkich założeń strategicznych. Dla celu „dopasowanie kapitału ludzkiego” wskazano dwa mierniki: liczbę pracowników podnoszących swoje kwalifikacje oraz strukturę wykształcenia pracowników. 
Pobrane z czasopisma Annales H - Oeconomia http://oeconomia.annales.umcs.pl

Data: 26/04/2023 15:53:24

POMIAR DOKONAŃ JEDNOSTKI SAMORZĄDU TERYTORIALNEGO PRZY WYKORZYSTANIU...

Tab. 3. Cele i mierniki w perspektywie procesów wewnętrznych strategicznej karty wyników dla gminy Inowrocław

\begin{tabular}{|l|l|}
\hline \multicolumn{1}{|c|}{ Cele strategiczne } & \multicolumn{1}{c|}{ Mierniki } \\
\hline P1. Skuteczna promocja gminy. & P1.1. Liczba turystów odwiedzających gminę. \\
\hline P2. Atrakcyjna oferta edukacyjna. & P2.1. Miejsce szkół w rankingu. \\
\hline $\begin{array}{l}\text { P3. Dostępna platforma komunikacji pomiędzy } \\
\text { sektorem publicznym, społecznym i gospodarczym. }\end{array}$ & $\begin{array}{l}\text { P3.1. Liczba zgłaszanych przez platformę sugestii } \\
\text { i uwag przez organizacje sektora publicznego, } \\
\text { społecznego i gospodarczego. }\end{array}$ \\
\hline P4. Wdrożenie systemu kontroli wydatków. & P4.1. Procent realizacji budżetu. \\
\hline $\begin{array}{l}\text { P5. Zapewnienie dobrze funkcjonującego systemu } \\
\text { obsługi klienta. }\end{array}$ & $\begin{array}{l}\text { P5.1. Poziom zadowolenia klientów z obsługi. } \\
\text { P5.2. Liczba spraw, które można załatwić przez } \\
\text { Internet. }\end{array}$ \\
\hline
\end{tabular}

Źródło: opracowanie własne na podstawie: [Strategia Rozwoju Gminy Inowrocław..., 2013, s. 21-22].

Osiągnięcie celu „dopasowanie kapitału informacyjnego” może być mierzone liczbą wydziałów połączonych systemem obiegu informacji. Dobrym miernikiem w przypadku dopasowania kapitału organizacyjnego będzie poziom znajomości przez pracowników strategii gminy Inowrocław. Cele strategiczne wraz z miernikami dla perspektywy wiedzy i rozwoju przedstawia tab. 4 .

Tab. 4. Cele i mierniki w perspektywie wiedzy i rozwoju strategicznej karty wyników dla gminy Inowrocław

\begin{tabular}{|l|l|}
\hline \multicolumn{1}{|c|}{ Cele strategiczne } & \multicolumn{1}{c|}{ Mierniki } \\
\hline R1. Dopasowanie kapitału ludzkiego. & $\begin{array}{l}\text { R1.1. Liczba pracowników podnoszących swoje } \\
\text { kompetencje. } \\
\text { R1.2. Struktura wykształcenia pracowników. }\end{array}$ \\
\hline R2. Dopasowanie kapitału informacyjnego. & $\begin{array}{l}\text { R2.1. Liczba wydziałów połączonych systemem } \\
\text { obiegu informacji. }\end{array}$ \\
\hline R3. Dopasowanie kapitału organizacyjnego. & $\begin{array}{l}\text { R3.1. Poziom znajomości przez pracowników } \\
\text { strategii gminy. }\end{array}$ \\
\hline
\end{tabular}

Źródło: opracowanie własne na podstawie: [Strategia Rozwoju Gminy Inowrocław..., 2013, s. 21-22].

Zaprezentowane mierniki finansowe i niefinansowe, przyporządkowane do celów strategicznych, mają za zadanie informować gminę o postępach w osiąganiu założonych celów. Monitorowanie przebiegu wdrażania strategii w gminie Inowrocław będzie realizowane przez [Strategia Rozwoju Gminy Inowrocław..., 2013, s. 22]:

- kontrolę postępu realizacji poszczególnych zadań i projektów wyznaczonych dla celów strategicznych,

- obserwację i ocenę stanu zaawansowania konkretnych projektów, umożliwiając bieżącą identyfikację trudności w ich realizacji,

- ocenę zaangażowania komórek organizacyjnych i osób odpowiedzialnych za ich wdrażanie,

- weryfikację zgodności z założonymi celami.

Analiza osiągniętych poziomów mierników w strategicznej karcie wyników będzie wykorzystana także do oceny efektywności wydatkowanych na ich realizację środków. 


\section{Zakończenie}

Strategiczna karta wyników to jedno z najefektywniejszych narzędzi pomiaru dokonań jednostek samorządu terytorialnego. Dzięki niej możliwe jest wyznaczenie celów strategicznych oraz monitorowanie przebiegu ich realizacji. Zgodnie z sugestiami twórców strategicznej karty wyników dla gminy Inowrocław opracowano system 24 mierników dla 18 celów strategicznych. Tak przygotowane narzędzie staje się systemem mierzenia efektywności i komunikowania wyników w procesie zarządzania gminą. Może również stanowić obszar do dalszych badań nad efektywnością jego wdrożenia.

\section{Bibliografia}

Bielawski R., Nowe ujęcie strategicznej karty wyników w realizacji strategii gminy, „Rozwój Regionalny w Liczbach. Studia i Materiały. Miscellanea Oeconomicae” 2014, nr 3.

Kaplan R.S., Norton D.P., Strategiczna karta wyników. Jak przełożyć strategię na działanie, Wydawnictwo Naukowe PWN, Warszawa 2001.

Niemiec A., Wykorzystanie kluczowych indykatorów osiąnięć (KPIs) w zintegrowanym zarzadzaniu ryzykiem, [w:] E. Urbańczyk (red.), Zarządzanie przedsiębiorstwem, Studia i Prace Wydziału Nauk Ekonomicznych i Zarządzania nr 7, Uniwersytet Szczeciński, Szczecin 2008.

Skoczylas W., Pomiar wyników w racjonalizacji zarządzania finansami jednostek samorządu terytorialnego, „Prace Naukowe Uniwersytetu Ekonomicznego we Wrocławiu” 2011a, nr 173.

Skoczylas W., Strategiczna karta wyników w pomiarze osiagnięć jednostki samorząu terytorialnego, „Zeszyty Naukowe Uniwersytetu Szczecińskiego. Finanse, Rynki Finansowe, Ubezpieczenia”2011b, $\mathrm{nr} 48$.

Świderek I., Budżet zadaniowy i strategiczna karta wyników w jednostkach samorzadu terytorialnego, ODDK, Gdańsk 2012.

Świerk J., Mapa strategii i strategiczna karta wyników w planowaniu działań przedsiębiorstwa, Wydawnictwo UMCS, Lublin 2009.

Zalewski A. (red.), Nowe zarzadzanie publiczne w polskim samorządzie terytorialnym, Szkoła Główna Handlowa w Warszawie, Warszawa 2007.

Strategia Rozwoju Gminy Inowrocław na lata 2013-2020, Westmor Consulting, Inowrocław 2013.

\section{Measuring the Performance of Local Government Using the Balanced Scorecard on the Example of Inowroclaw Community}

Balanced Scorecard seems to rise as a solution being used more and more in the process of implementing of local government development strategies. It is most useful as a way of translation from mission and strategy to operating activity. Success of local authorities and government units can be assessed by using of financial and non-financial measures described in BSC. The main goal of this article is to present the conception of issue of local activity measuring and to show how wide is perspective and possibility of Balanced Scorecard if using in measuring of strategy realization based on the example of Inowrocław community. 
Pobrane z czasopisma Annales H - Oeconomia http://oeconomia.annales.umcs.pl Data: 26/04/2023 15:53:24

POMIAR DOKONAŃ JEDNOSTKI SAMORZĄDU TERYTORIALNEGO PRZY WYKORZYSTANIU...

\section{Pomiar dokonań jednostki samorządu terytorialnego przy wykorzystaniu strategicznej karty wyników na przykładzie gminy Inowrocław}

Strategiczna karta wyników to koncepcja coraz częściej wykorzystywana do wdrażania strategii rozwoju jednostki samorządu terytorialnego. Umożliwia przełożenie misji i strategii na działania operacyjne. Przez ustalone mierniki, finansowe i niefinansowe, staje się systemem mierzenia efektywności dokonań gminy. Celem artykułu jest ukazanie istoty pomiaru dokonań jednostki samorządu terytorialnego oraz zaprezentowanie możliwości zastosowania strategicznej karty wyników do mierzenia realizacji strategii rozwoju gminy Inowrocław. 